\title{
Mental health and dropout behavior: A cross-sectional study of junior high students in northwest rural China
}

\author{
Wang Huan ${ }^{\mathrm{a}, 1}$, Chu Yang ${ }^{\mathrm{a}, 2}$, He Fei ${ }^{\mathrm{b}, 3}$, Shi Yaojiang ${ }^{\mathrm{c}, *}$, Qinghe $\mathrm{Qu}^{\mathrm{d}, 4}$, Scott Rozelle ${ }^{\mathrm{e}, 5}$, \\ James Chu ${ }^{\mathrm{e}, 6}$ \\ a School of Economics and Management, Northwest University, 710127 Xi'an, Shaanxi, China \\ ${ }^{\mathrm{b}}$ School of Philosophy and Sociology, Northwest University, 710127 Xi'an, Shaanxi, China \\ 'Center for Experimental Economics for Education, Shaanxi Normal University, 710119 Xi'an, Shaanxi, China \\ ${ }^{\mathrm{d}}$ Center for Chinese Agricultural Policy, Institute of Geographical Sciences and Natural Resources Research, Chinese Academy of Sciences, 100101 Beijing, \\ China \\ ${ }^{\mathrm{e}}$ Freeman Spogli Institute for International Studies, Stanford University, Stanford, CA 94305-6055, United States
}

\section{A R T I C L E I N F O}

\section{Keywords:}

Mental health

Rural China

Junior high

Dropout

\begin{abstract}
A B S T R A C T
Background: Junior high dropout rates are up to $25 \%$ in poor, rural areas of China. Although existing studies have examined how factors such as high tuition and opportunity costs contribute to dropout, fewer studies have explored the relationship between dropout rates and mental health in rural China. The overall goal of this study is to examine the relationship between dropout and mental health problems in rural Chinese junior high schools.

Methods: Correlational analysis was conducted among 4840 students across 38 junior high schools in rural China. Ordinary least squares (OLS) regressions were used to determine the types of students most at risk for mental health problems and whether mental health problems are correlated with dropout behavior. Our measure for mental health is based on the Children's Manifest Anxiety Scale.

Results: Mental health problems are widespread in the sample of rural children, with $74 \%$ of students at risk for mental health problems. The student and family characteristics that correlate with dropout (poverty and low achievement) also correlate with mental health problems. More importantly, even after controlling for these background characteristics, mental health problems remain correlated with dropout rates.

Conclusions: Mental health problems, especially among low-achieving poor students, may be contributing to the high dropout rates in rural China today. This finding suggests that interventions focusing on mental health in rural areas may also help reduce dropout.
\end{abstract}

(c) 2014 Elsevier Ltd. All rights reserved.

\section{Introduction}

A critical question that China faces is how to effectively build human capital to promote and sustain economic growth. As the

\footnotetext{
* Corresponding author. Tel.: +86 1389283 3777; fax: +86 02988308337.

E-mail addresses: wanghuan1206@gmail.com (H. Wang), yangchu1031@gmail.com (C. Yang), hefei0913@163.com (F. He), shiyaojiang7@gmail.com (Y. Shi), qhqu.ccap@igsnrr.ac.cn (Q. Qu), rozelle@stanford.edu (S. Rozelle), jchu1225@stanford.edu (J. Chu).

${ }^{1}$ Tel.: +86 1357187 0447; fax: +86 02988308337 .

${ }^{2}$ Tel.: +861871030 0390; fax: +8602988308337.

${ }^{3}$ Tel.: +861862933 5155; fax: +8602988308337.

${ }^{4}$ Tel.: +86 1510115 7254; fax: +86010 64856533 .

${ }^{5}$ Tel.: +1 650862 0466; fax: +1 6507251992.

${ }^{6}$ Tel.: +1 650804 5735; fax: +1 6507251992 .
}

economies of developing countries shift from lower value-added to higher value-added industries and experience technological change, their need for human capital also increases (Heckman and Yi, 2012; Yi et al., 2012; Autor et al., 2003). Indeed, higher valueadded jobs must be staffed with employees who are equipped with greater skills (Bresnahan et al., 2002; Bresnahan, 1999). Without a labor force with sufficient skills, developing economies could ultimately stagnate (Hanushek and Woessmann, 2012, 2008). In the long run a surplus of unemployed or informal-sector workers may lead to social instability (Yi et al., 2012).

Unfortunately, instead of staying in school (through high school or beyond) and accumulating human capital, many students in China-especially in poor rural areas-are dropping out of school before they finish junior high school. In fact, recent research on dropouts has found high rates in many different settings. Yi et al. (2012) found that the cumulative grade 7 and 8 dropout rate in 
poor rural China is $14.2 \%$. When looking at all three years of junior high in these schools together, up to one in four rural Chinese students dropped out before graduating. This rate is nearly 10 times higher than the officially recognized 3-year cumulative junior high school dropout rate of 2.6\%. Mo et al. (2011) found similarly high dropout rates. Other research conducted in rural China has found junior high dropout rates as high as 56\% (Connelly and Zheng, 2003; Brown and Park, 2002).

The literature in China and other developing countries has identified a number of traditional factors-factors that we call economic factors-that are associated with high rates of dropout. High rates of dropout (as well as low rates of educational attainment) have been found to be associated with poverty (Brown and Park, 2002; Filmer, 1999). Even when school tuition and fees are zero (and poverty per se is not an issue), dropout has often been observed when education systems are competitive (Glewwe and Kremer, 2006). In competitive educational systemswhere there is only limited space in schools, quality-based tracking, and high-stakes entrance examinations-the probability of student dropout has been shown to be high (Clarke et al., 2000; Reardon and Galindo, 2002). Finally, increasing wages in the unskilled labor market may drive students out of school as the opportunity cost of schooling rises. When unskilled wage rates rise, students reduce their educational attainment targets even when schooling is free (Angrist and Lavy, 2009; Fizbein and Shady, 2009).

Economic factors alone, however, do not fully explain why students drop out. For example, Mo et al. estimated the impact of a conditional cash transfer (CCT), which promised cash to students if they were still in school at the end of the semester and maintained $80 \%$ attendance, on student dropout behavior among seventh graders in a poor county in inland China (Mo et al., 2011). Although the program reduced dropout rates by around 60\% (from 13 to 5\%), $40 \%$ of the seventh graders receiving the CCT still dropped out. This fact suggests that non-economic factors also may be affecting student dropout. When discussing the determinants of dropout, Yi et al. (2012) found that traditional factors, such as poverty, only explain roughly $8 \%$ of the variation in dropout rates. Indeed, studies in other countries and contexts suggest the importance of non-economic factors in student dropout (Reardon and Galindo, 2002).

Compared with economic factors, much less attention has been paid to the role of one non-economic factor-adverse psychological pressure-on low educational performance and dropout in the context of developing countries (such as China). Research on education in developed countries has shown that psychological factors, such as anxiety (Chen and Li, 2000), depression (NolenHoeksema et al., 1986) and aggression and impulsiveness (Kokko et al., 2006), are strong determinants of poor educational performance and dropout. However, research on these issues in developing countries is still limited. Existing studies focus primarily on the relationship between mental health problems and educational performance in developed countries (Currie, 2009; Bloom and Canning, 2000; Pintrich and De Groot, 1990). Although there have been a number of studies examining mental health problems in China (see for example, Chen and Li, 2000), such studies almost always focus on richer, developed areas along the coast. To our knowledge, there have been no studies on rural Chinese students.

There are two reasons mental health problems are of particular concern in rural China. First, the Chinese government is also concerned about mental health problems in rural areas. The Ministry of Education recently published a circular to all provincial education departments, requesting that they improve the mental health of junior high students, especially in rural areas (MoE 2012). Second, rural areas may be at high risk of poor mental health for several reasons. There is a high prevalence of single-parent families or being "left-behind" when their parents migrate (Zhang, 2006; Qiao et al., 2008). Rural students tend to have less academic achievement than urban students (Luo et al., 2012). In the context of the competitive education system, rural students may be anxious about their ability to continue with their education (Yi et al., 2012).

The overall goal of this study is to examine the general relationship between dropout and mental health problems in junior high schools in rural China. To meet this goal, we pursue three specific objectives. First, we document the prevalence of risk for both dropout and mental health problems among junior high students in rural China. Second, we identify the student and family characteristics correlated with risk for dropout and mental health problems. Third, we examine whether mental health problems are correlated with student dropout both before and after controlling for student and family characteristics.

The rest of the paper is organized as follows. Section 2 introduces the sampling, the collection of data and the way we measure dropout and mental health. Section 3 reports the rates of prevalence and correlates of risk for dropout and mental health problems. Section 4 analyzes the relationship between dropout and mental health problems. Section 5 concludes.

\section{Methods}

\subsection{Sampling}

Our study sample is located in a prefecture in northern Shaanxi Province. In 2012, the per capita rural income in our sample area was $7681 \mathrm{RMB}$ (or \$1238). When compared to other rural areas in Shaanxi, our sample area is not the poorest prefecture: the per capita rural income is $\$ 309$ higher than the average per capita rural income of Shaanxi province. However, this prefecture remains broadly representative of rural areas in China's northwest region. The prefecture has relatively poor agricultural resources and poor transportation infrastructure. Indeed, the per capital rural income in this prefecture is $\$ 38$ (or 3\%) lower than the average per capita income in rural China (CNBS, 2012).

From this prefecture, we sampled eight counties. To do so, we first obtained a list of all the twelve counties in this Prefecture. Due to constraints in our research budget, the research team chose the most populous eight counties to enroll in our sample. The population of these eight counties constitutes $84 \%$ of all of our sample prefecture.

The next step was to choose the sample of junior high schools. To do so, we collected a list of all junior high schools in the eight sample counties from the local bureaus of education. There were a total of 170 junior high schools. We then applied two exclusion criteria to these 170 schools. First, because our interest is in rural schools, we excluded junior high schools that primarily enrolled urban students. There were 12 such schools. Second, because China's government is currently consolidating existing rural schools into new ones, to safeguard against excessive attrition, we excluded schools with fewer than 100 students (50 students in seventh and eighth grade, respectively). After applying exclusion criteria, we had 75 schools. We then randomly chose half of them (38) as our sample schools. For a summary of the distribution of schools and students in our sample, please see Table 1.

In each sample school, we enrolled all students in seventh and eighth grade into our sample. There were, on average, 127 seventh and eighth grade students per school. In total, 4840 seventh and eighth-grade students participated in the study. Taken together, our sample is roughly representative of junior high students in poor, rural areas of inland China. 
Table 1

Distribution of sample schools and students.

\begin{tabular}{llll}
\hline Item & No. of schools & No. of students & \% of students \\
\hline Total sample & 38 & 4840 & 100 \\
By county & & & \\
County 1 & 9 & 1073 & 22 \\
County 2 & 4 & 606 & 13 \\
County 3 & 4 & 631 & 13 \\
County 4 & 6 & 982 & 20 \\
County 5 & 5 & 371 & 8 \\
County 6 & 3 & 470 & 10 \\
County 7 & 4 & 509 & 4 \\
County 8 & 3 & 198 & 46 \\
By gender & & 2250 & 54 \\
Female & & 2590 & \\
Male & &
\end{tabular}

\subsection{Data collection}

In each of the sample schools, our enumeration teams conducted a two-part survey among all 4840 students in October 2012, which is at the beginning of 2012-2013 academic year. The first part of the survey was a mental health test (MHT). The MHT contained 100 yes/no questions. The purpose of the test was to measure each student's general anxiety. The MHT was administrated and proctored by our survey team in the classroom.

The test is scored in the following manner. Of the 100 test questions, 10 are used to detect whether the student is answering honestly (or purposely mis-answering questions). These are called reliability questions. If the student answered yes to more than 7 of these questions the test is considered invalid. Invalid tests are not used in the analysis. The remaining 90 points make up the students' MHT score, where a lower score corresponds to lower risk for mental health problems. A total score of 65 or higher indicates high risk for mental health problems and indicates a need for professional help.

The test results can be broken down into eight subcategories. Each subcategory represents a specific aspect of anxiety: learning anxiety, personal anxiety, loneliness, self-blaming tendency, sensitivity tendency, body anxiety, phobia anxiety and impulsiveness. A score over 7 on any subsection is considered clinically anxious. When a student scores more than 7 (that is, 8 or higher) on any subsection, it is indicative of a need for assessment and potential treatment by a clinical psychologist.

The MHT has been shown in the literature to produce a reliable measure of general anxiety. The test is a variation of the Children's Manifest Anxiety Scale (CMAS). The CMAS is a scale that has been widely used in the United States and other developed countries, for more than a decade as a screening and clinical tool. Professor Zhou Bucheng of East China Normal University developed the mental health test scale used in this study. Researchers have used this test extensively across China to measure the mental health of grade school students in urban contexts (Deng et al., 2002). The MHT has a reliability of $0.84-0.88$ and a retest reliability of $0.78-0.86$ (Wang, 2011). This high retest reliability shows that the MHT measures an aspect of mental health that is stable over time. A complete list of questions in the MHT is included in Table A1 for the interested reader.

The second part of the survey collected data on the basic socioeconomic information of each student. The survey form asked about each student's gender, age, family structure, and their parents' education status. Enumerators also asked students about where they lived during most of the school year-at home or in the school's boarding dormitories. Students were also asked to fill out a checklist of household consumption assets. A value was attached to each asset (based on the National Household Income and Expenditure Survey, which is organized and published by the China National Bureau of Statistics-CNBS, 2008) to produce a single metric of household asset holdings. Summing the value of all household consumption assets then produced our proxy variable for family asset value.

A standardized mathematics test was also administered and proctored by our survey team in the classroom. Students had $25 \mathrm{~min}$ to complete the test. The mathematics test was based on a subset of a test originally created for the trends in international mathematics and science study (TIMSS).

In order to examine the correlation between drop out and mental health problems, we conducted a follow-up survey in September 2013 (at the beginning of the 2013-2014 academic year) and tracked all the students in our sample. We adhered to the following protocol in order to track the same students as in the first round survey. First, we collected the name and contact information of each student in the 2012 baseline survey. Second, the enumerators were asked to record the attendance of each student during the 2013 follow-up survey. If the students were absent, the enumerators were to ask the homeroom teacher for the reason for absence on the survey day (coded as transferred to other schools, dropped out, or on temporary leave due to being ill) to further confirm whether they had dropped out of school or were temporarily absent. Regardless of the answer given by the homeroom teacher, a similar set of question were asked of the class captain, a student who is elected by his/her peers to act as an administrative liaison between the students in the class and the teacher. If there was a discrepancy between the homeroom teacher and class captain, we called the student's home and asked the parents or the caregiver about the status of the student.

\subsection{Analytical approach}

We first run descriptive analyses. In the very initial analyses we look at the prevalence rates of dropouts and those students with mental health problems. To understand what kinds of students are more likely to drop out, we then compare the mental health "at-risk rate" (percent of students who scored 7 or higher in any of the eight subcategories of the MHT test) and dropout rate between different student and family characteristics: student gender, age, boarding status, grade, academic performance, as well as family characteristics including whether the student is an only child, the education level of parents, and household consumption asset value. We use $t$-tests to measure if there is a significant difference between those groups and analyze which characteristics are correlated with mental health problems and dropout.

In estimating the correlation between mental health status and drop out, we use ordinary least squares (OLS), including a set of covariates in a regression on student dropout. We first run an unadjusted regression (1):

$Y_{i j}=\alpha+M H T_{i}+\epsilon_{i}$

The dependent variable $Y_{i j}$ indicates the dropout status of student $i$ in school $j$, which equals 1 if the student has dropped out in 2013 and equals 0 if the student remained in school. $M H T_{i}$ is the standardized score of the students on the MHT test, which indicates the mental health status of student $i$.

To control for the potential confounding effects of student and family characteristics, we run multivariate analysis building on Eq. (1) above but with the addition of a vector of control variables.

$Y_{i j}=\alpha+\beta M H T_{i}+\gamma X_{i}+\epsilon_{i}$ 
The vector $X_{i}$ includes student individual characteristics and family characteristics. The student individual characteristics include student gender (the variable equals 1 if the student is female and equals 0 if the student is male), student age (in years), boarding (the variable equals 1 if the student is boarding student and equals 0 if the student is non-boarding), student grade (the variable equals 1 if the student is grade 7 and equals 0 if the student is grade 8 ), student academic performance (the variable equals 1 if the student's math test score is in the lowest quartile and equals 0 if the student's math test score is higher than the lowest quartile) as well as whether the student is only child (the variable equals 1 if the student is the only child and equals 0 if the student has siblings). The family characteristics include the education level of parents (the variable equals 1 if the father/mother of the student has graduated from junior high school or above and equals 0 if he/ she has not graduated from junior high school, respectively) and household consumption asset value (the variable equals 1 if the household is in the lowest quartile and equals 0 if the household is higher than the lowest quartile).

Finally, to further improve efficiency, we add school-level fixed effects, represented by $\varphi_{j}$. We run multivariate analysis as Eq. (3) below:

$Y_{i j}=\alpha+\beta M H T_{i}+\gamma \boldsymbol{X}_{i}+\varphi_{j}+\epsilon_{i}$

In all Eqs. (1)-(3), we compute heteroskedasticity-robust standard errors (adjusted for clustering at the school level).

\section{The prevalence and correlates of dropout and mental health problems}

\subsection{Dropout rates}

In fact, the background of students in our sample (both in homes and at school) accords with existing studies that show an overall lack of resources and care for mental health issues in rural China. For example, only $8 \%$ of students had a father who completed junior high school and only $5 \%$ of students had a mother who completed junior high. Moreover, the students in our sample have parents largely in occupations that are low paying and low status (often requiring the parents to work away from home). More specifically, in our sample, $69 \%$ of students had fathers whose main occupation was either farming or working as a migrant laborer. Similarly, $62 \%$ of students had mothers whose main occupation was either farming or working as a migrant laborer. The schools are also set up in a way that suggests lack of resources and care for mental health issues. Although the student to teacher ratio is 6.2 to 1 , only $16 \%$ of the schools reported having any school resources (like school counselors) to address student mental health issues. In our experience, even schools with a school counselor do not employ them in this capacity.

According to our data, the dropout rate over one academic year is, on average, $6.8 \%$. This rate, however, varies by grades. The dropout rate is $4.4 \%$ for grade 7 students. The dropout rate is $9.0 \%$ for grade 8 students. This, of course, means that in our sample schools, $13 \%$ of students are dropping out during their grade 7 and grade 8 years. These are slightly lower than the $5.7 \%$ dropout rate for seventh graders and 9\% dropout rate for eighth graders (or a rate of $14.7 \%$ when looking at the two-year dropout rate) found by Yi et al. (2012). Although our sample area is still considered a poor, rural area, the dropout may be slightly less than those reported by Yi et al. because our sample prefecture is richer than the area studied by Yi et al. This level of dropout, just in the first academic year of junior high school, is five times higher than the officially recognized level for all three grades of junior high: $2.6 \%$.

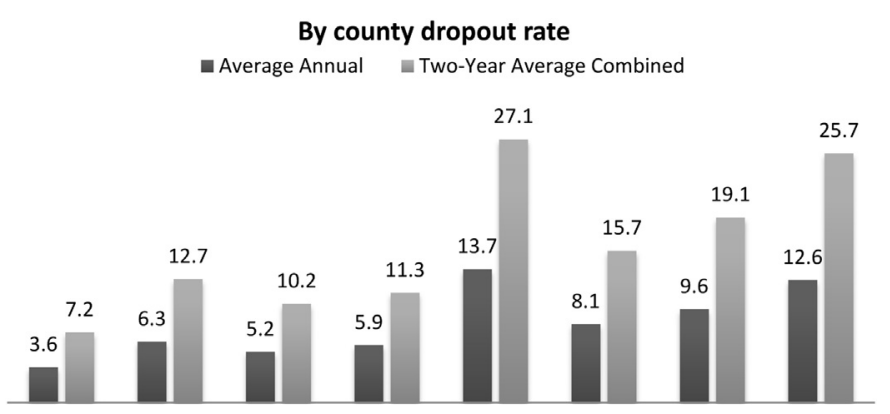

County 1 County 2 County 3 County 4 County 5 County 6 County 7 County 8

Fig. 1. Dropout rate by county.

Our data also demonstrate that dropout rates vary across counties. We find that the range of average annual dropout rates goes from $3.6 \%$ to $13.7 \%$, the average combined two-year dropout rate ranges from $7.2 \%$ to $27.1 \%$ (Fig. 1 ).

\subsection{Prevalence of mental health problems}

Before analyzing results for mental health, we first drop students who failed the MHT reliability check. We found that 3.7\% of students failed the reliability check in the MHT. This means that overall $96.3 \%$ of the sample students took the MHT seriously. Importantly, there exist no significant differences between the group of students who passed the reliability check and those who did not. Specifically, in Table 2 we find that the two groups of students had no significant difference of their basic characteristics or gender differences. Eliminating the students who did not pass the reliability test had no significant effect on overall sample. Therefore, removing these $3.7 \%$ of students from the sample has no impact on our external validity. Moreover, according to Fig. 2 ,

Table 2

Comparison of participant characteristics of students who passed/did not pass MHT reliability check.

\begin{tabular}{|c|c|c|c|}
\hline Key characteristics & $\begin{array}{l}\text { Did not pass } \\
\text { reliability } \\
\text { check } \\
\text { Mean } \\
(S D)\end{array}$ & $\begin{array}{l}\text { Passed } \\
\text { reliability } \\
\text { check } \\
\text { Mean } \\
(S D)\end{array}$ & Difference \\
\hline Observations & 175 & 4665 & \\
\hline [1] Female, 1 =female & $\begin{array}{l}0.42 \\
(0.50)\end{array}$ & $\begin{array}{l}0.47 \\
(0.50)\end{array}$ & 0.05 \\
\hline [2] Age, years & $\begin{array}{l}13.61 \\
(1.16)\end{array}$ & $\begin{array}{l}13.47 \\
(1.15)\end{array}$ & 0.14 \\
\hline [3] Boarding, 1 = boarding, & $\begin{array}{l}0.71 \\
(0.46)\end{array}$ & $\begin{array}{l}0.64 \\
(0.48)\end{array}$ & 0.07 \\
\hline [4] 7th Grade, $1=7$ th & $\begin{array}{l}0.48 \\
(0.50)\end{array}$ & $\begin{array}{l}0.48 \\
(0.50)\end{array}$ & 0.00 \\
\hline $\begin{array}{l}\text { [5] Math scores in lowest } \\
25 \text { percent } 1=\text { yes }\end{array}$ & $\begin{array}{l}0.31 \\
(0.47)\end{array}$ & $\begin{array}{l}0.30 \\
(0.45)\end{array}$ & 0.02 \\
\hline [6] Only child, $1=$ only child & $\begin{array}{l}0.13 \\
(0.33)\end{array}$ & $\begin{array}{l}0.12 \\
(0.35)\end{array}$ & 0.00 \\
\hline $\begin{array}{l}\text { [7] Father completed } \\
\text { junior HS, } 1=\text { yes }\end{array}$ & $\begin{array}{l}0.41 \\
(0.49)\end{array}$ & $\begin{array}{l}0.46 \\
(0.50)\end{array}$ & -0.05 \\
\hline $\begin{array}{l}\text { [8] Mother completed } \\
\text { junior HS, } 1=\text { yes }\end{array}$ & $\begin{array}{l}0.25 \\
(0.43)\end{array}$ & $\begin{array}{l}0.26 \\
(0.44)\end{array}$ & -0.02 \\
\hline $\begin{array}{l}\text { [9] Asset value in } \\
\text { lowest } 25 \text { percent }\end{array}$ & $\begin{array}{l}0.25 \\
(0.43)\end{array}$ & $\begin{array}{l}0.25 \\
(0.43)\end{array}$ & 0.00 \\
\hline
\end{tabular}

$T$-statistics adjusted for clustering within schools. Different from zero, ${ }^{*} P \leq 0.10$, ** $P \leq 0.05$, ${ }^{* * *} P \leq 0.01$ 


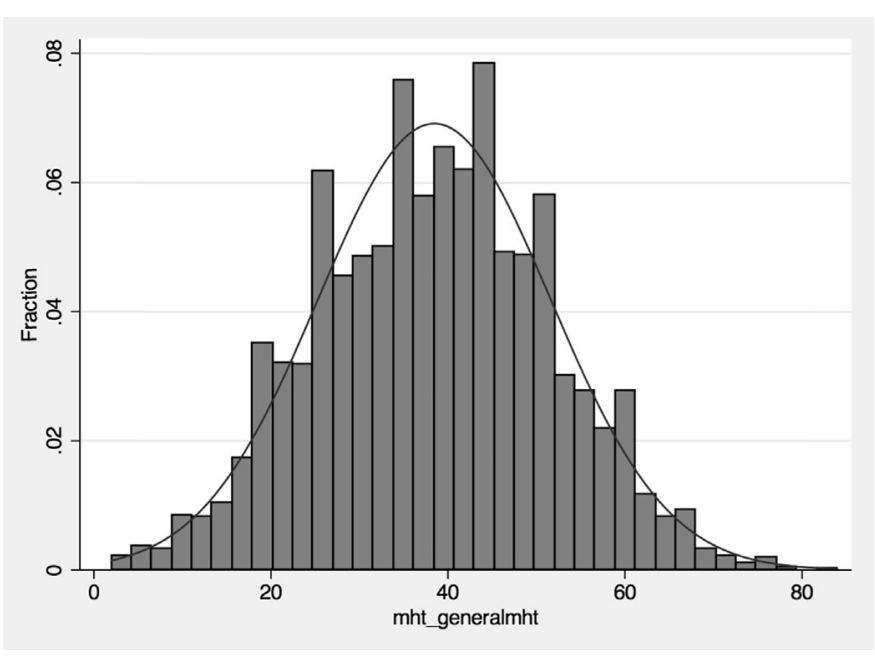

Fig. 2. Histogram of MHT scores.

the distribution of MHT scores follows a normal distribution. The mean of the distribution is 38.2 and the standard deviation is 13.3.

When examining our sample of 4665 students who passed the reliability check, we find that the risk for mental health problems is high in rural Chinese junior high schools. According to our data, more than $74 \%$ of grade 7 and 8 students in poor rural junior high schools had at least one aspect of anxiety (Table 3, row 1). This finding means that $74 \%$ of children in rural China may need support from a clinical psychologist.

When we decompose these measures, we find that learning anxiety appears to be driving the mental health problems in our rural China sample junior high schools. Specifically, we find that the subscales affecting the highest proportion of students are learning anxiety, body anxiety, and self-blaming tendency respectively (see Fig. 3). Of the overall sample, $66 \%$ of students had learning anxiety tendencies; $22 \%$ had body anxieties; $19 \%$ had self-blaming tendencies; and $17 \%$ had sensitivity tendencies (Table 3, Column 4, rows 2, 5, 6, 7, 8). The other types of mental health problems are of much lower prevalence. For example, only $2 \%$ and $4 \%$ students reported loneliness anxiety and impulsive tendencies, respectively.

What does learning anxiety actually mean? According to the MHT test, learning anxiety refers to a student's fear of examinations or excessive concerns about test scores. Specifically, when students filled out the 15 items in the learning anxiety tendency scale, 93\% indicated that they were worried about passing exams successfully (Table A1, row 9). Moreover, 79\% students feel unhappy when their test scores are not good, $79 \%$ feel anxious

Table 3

Categorical breakdowns of the mental health test score.

\begin{tabular}{lrrrc}
\hline Category & Obs. & $\begin{array}{l}\text { Mean } \\
\text { Points }\end{array}$ & SD Points & At-risk $^{\mathrm{c}} \%$ \\
\hline [1] General MHT score & 4665 & 38.46 & 13.13 & 74 \\
[2] Learning anxiety $^{\mathrm{a}}$ & 4665 & 8.62 & 3.00 & 66 \\
[3] Personal anxiety $^{\mathrm{b}}$ & 4665 & 4.35 & 2.26 & 9 \\
[4] Loneliness anxiety $^{\mathrm{b}}$ & 4665 & 2.73 & 2.02 & 2 \\
[5] Self-Blaming tendency $^{\mathrm{b}}$ & 4665 & 5.34 & 2.34 & 19 \\
[6] Sensitivity tendency $^{\mathrm{b}}$ & 4665 & 5.38 & 2.15 & 17 \\
[7] Body anxiety $^{\mathrm{a}}$ & 4665 & 5.28 & 2.79 & 22 \\
[8] Phobia anxiety $^{\mathrm{b}}$ & 4665 & 3.78 & 2.67 & 10 \\
[9] Impulsive tendency $^{\mathrm{b}}$ & 4665 & 2.99 & 2.26 & 4 \\
\hline
\end{tabular}

a Maximum MHT score of this category equals to 15 points.

b Maximum MHT score of this category equals to 10 points.

c At risk is defined as percentage of kids who have $7+$ points in any category.

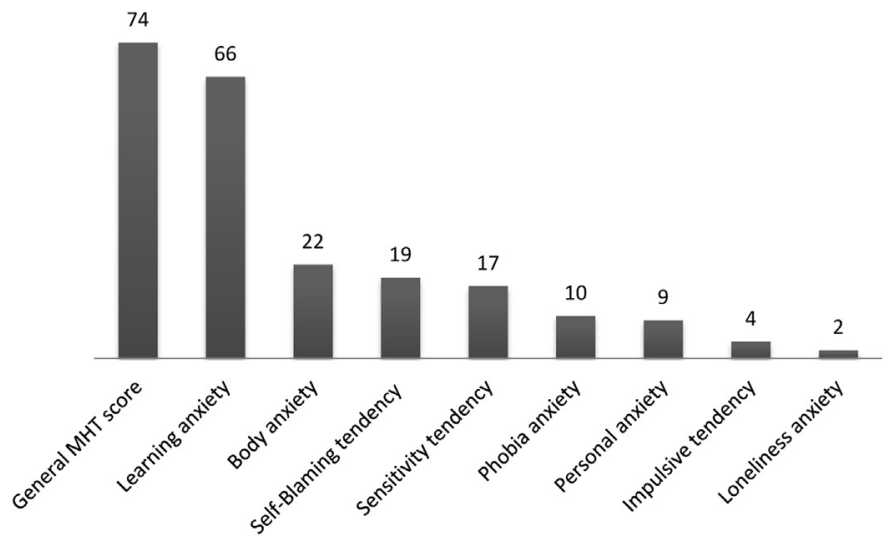

Fig. 3. Percent bar graph of categorical breakdown MHT.

when they cannot remember what they have learned during an examination, and $66 \%$ worry about getting a poor score when they take an exam. In sum, anxiety about examination scores and educational performance appears to be one of the chief sources of mental health problems in our sample's poor rural junior high schools.

\subsection{Who drops out? Who has mental health problems?}

We find that students who drop out tend to be boys, older, have lower academic achievement, and come from more disadvantaged family backgrounds (boarding at school, more siblings, and parents with less education and lower family asset value-Table 4). For example, boys are 3 percentage points more likely to drop out than girls (Table 4, row 1 ). Students older than 14 years have a dropout rate of $10.7 \%$, which is more than five times higher than those younger than 14 (row 2). Dropouts also tend to be students who are

Table 4

Who is more likely to drop out?

\begin{tabular}{|c|c|c|c|c|}
\hline \multirow[t]{2}{*}{ Characteristics } & \multicolumn{4}{|c|}{ Dropped out } \\
\hline & $\%$ & $N$ & Difference & $|t|$ \\
\hline \multicolumn{5}{|l|}{ [1] Gender } \\
\hline Female & 4.55 & 98 & 0.03 & $4.01^{* * * *}$ \\
\hline Male & 7.36 & 181 & & \\
\hline \multicolumn{5}{|l|}{ [2] Age-group } \\
\hline$\leq 13$ & 1.96 & 48 & -0.09 & $16.54^{* * *}$ \\
\hline$\geq 14$ & 10.66 & 231 & & \\
\hline \multicolumn{5}{|l|}{ [3] Boarding } \\
\hline Does not board & 4.89 & 81 & -0.02 & $2.48^{*}$ \\
\hline Boards & 6.70 & 198 & & \\
\hline \multicolumn{5}{|l|}{ [4] Grade } \\
\hline 7th & 4.45 & 93 & 0.04 & $5.19^{* * *}$ \\
\hline 8th & 9.01 & 186 & & \\
\hline \multicolumn{5}{|l|}{ [5] Math score } \\
\hline In highest 25 percent & 2.60 & 16 & -0.04 & $4.70^{* * *}$ \\
\hline In lowest 25 percent & 8.61 & 116 & & \\
\hline \multicolumn{5}{|l|}{ [6] Sibling } \\
\hline Only child & 4 & 23 & 0.02 & $2.20^{* *}$ \\
\hline Has siblings & 6.34 & 256 & & \\
\hline \multicolumn{5}{|l|}{ [7] Education of fathers } \\
\hline Not completed Junior HS & 6.87 & 172 & 0.02 & $2.55^{* *}$ \\
\hline Completed Junior HS and above & 5.07 & 107 & & \\
\hline \multicolumn{5}{|l|}{ [8] Education of mothers } \\
\hline Not completed Junior HS & 6.17 & 210 & 0.01 & 0.61 \\
\hline Completed Junior HS and above & 5.68 & 69 & & \\
\hline [9] Asset value & & & & \\
\hline In highest 25 percent & 5.65 & 64 & -0.02 & $2.57^{* *}$ \\
\hline In lowest 25 percent & 7.62 & 87 & & \\
\hline
\end{tabular}

Robust standard errors in parentheses ${ }^{* * *} p<0.01,{ }^{* *} p<0.05,{ }^{*} p<0.1$. 
doing relatively poorly in their academic studies, those students had little chance of moving up through the education system. Students that rank below the 25 th percentile in their class dropout at a rate of $8.6 \%$ versus those ranking above the top 25th percentile, who only drop out at a rate of $2.6 \%$ (row 5 ). According to our results, we also find that students from more disadvantaged family backgrounds tend to drop out more. For example, students that board at school (where boarding is typically an activity of the children of poorer families) drop out at a rate of $6.7 \%$ ( 2 percentage points higher than the non-boarding students, a difference is significant at the $10 \%$ level-row 3 ). In addition to signaling that the student is from a relatively less-wealthy family, students who board at school may be further disadvantaged by poor living conditions (e.g. Luo et al., 2012). Finally, students with siblings are 2 percentage points more likely to drop out compared with students without siblings. One possible interpretation is that students with siblings face more pressure at home, since their parents may save the scarce educational opportunities for their siblings (Angrist and Lavy, 2009). Most prominently, students in the lowest quartile of consumption asset value drop out at a rate of $7.6 \%$, which is 2 percentage points higher than students in the highest quartile of consumption asset value (row 9).

Interestingly, these variables are similar to those found by Yi et al. (2012) and can be interpreted more or less the same way. In their paper, Yi and coauthors interpreted the fact that boys and older students drop out to mean that those students with higher opportunity costs were at higher risk of dropping out. In other words, perhaps it is easier for older boys to be employed as lowskilled workers (Mo et al., 2011). Indeed, students in China are allowed to enter the labor market at 16 years old. Although students are not technically allowed to drop out until they finish nine years of compulsory schooling, the fact that they can legally enter the labor market incentivizes many of them to drop out. Indeed, the dropout rate for the students who are younger than 16 years old is $5 \%$, whereas the dropout rate for the students who are older than 16 years old is $28 \%$, nearly 6 times higher than the younger students.

As with Yi et al. (2012), we also find that students with lower academic achievement and students from poor families are at high risk of dropping out.

Significantly, with exception to gender, the same kinds of students who are more likely to drop out are also at risk for mental health problems. According to cross tabulations from our data, girls, older students, students who have low academic achievement, and students who come from more vulnerable family backgrounds (e.g. parents have less education) are most likely to be at risk for mental health problems (Table 5).

Girls are less likely to drop out but more vulnerable to be at risk to have mental health problems than boys. In our data, $78 \%$ of girls were at risk for mental health problems (or 8 percentage points higher than boys-Table 5, row 1 ). While we cannot be sure, girls might be less likely to dropout but more anxious because girls tend to face more social expectations regarding their behavior (Wang et al., 2012). These expectations may incentivize them to stay in school but may also simultaneously cause more stress and anxiety. $^{7}$

\footnotetext{
${ }^{7}$ Indeed, as it turns out, girls are also more susceptible to the main measure of the mental health measure: severe learning anxiety. Girls are 9 percentage points more likely to face severe learning anxiety (this difference is significant at $1 \%$ level-table omitted for brevity and available upon request). This is surprising since girls in rural China appear to be subject to equal or lower expectations and aspirations about school performance from their parents and teachers (compared to boys-see Hannum \& Adams, 2007). However, it may also be that girls are more sensitive than boys to the expectations and aspirations about their performance.
}

Table 5

Who is at risk of having mental health problems (scored 7 or higher on any of the subcategories of the MHT test)?

\begin{tabular}{|c|c|c|c|c|}
\hline \multirow[t]{2}{*}{ Characteristics } & \multicolumn{4}{|c|}{ At-risk } \\
\hline & $\%$ & $N$ & Difference & $|t|$ \\
\hline \multicolumn{5}{|l|}{ [1] Gender } \\
\hline Female & 78 & 1705 & 0.08 & $5.90^{* * *}$ \\
\hline Male & 70 & 1742 & & \\
\hline \multicolumn{5}{|l|}{ [2] Age-group } \\
\hline$\leq 13$ & 72 & 1773 & 0.05 & $3.22 * * *$ \\
\hline$\geq 14$ & 76 & 1674 & & \\
\hline \multicolumn{5}{|l|}{ [3] Boarding } \\
\hline Does not board & 73 & 1208 & 0.02 & 1.42 \\
\hline Boards & 75 & 2239 & & \\
\hline \multicolumn{5}{|l|}{ [4] Grade } \\
\hline 7th & 73 & 1619 & 0.03 & $1.93^{*}$ \\
\hline 8th & 75 & 1828 & & \\
\hline \multicolumn{5}{|l|}{ [5] Math score } \\
\hline In highest 25 percent & 65 & 403 & 0.05 & $5.54^{* * *}$ \\
\hline In lowest 25 percent & 77 & 1047 & & \\
\hline \multicolumn{5}{|l|}{ [6] Sibling } \\
\hline Only child & 74 & 408 & -0.02 & 1.68 \\
\hline Has siblings & 70 & 3039 & & \\
\hline \multicolumn{5}{|l|}{ [7] Education of fathers } \\
\hline Not completed Junior HS & 76 & 1920 & 0.04 & $2.91^{* * *}$ \\
\hline Completed Junior HS and above & 72 & 1527 & & \\
\hline \multicolumn{5}{|l|}{ [8] Education of mothers } \\
\hline Not completed Junior HS & 74 & 2555 & 0.01 & 0.62 \\
\hline Completed Junior HS and above & 73 & 892 & & \\
\hline \multicolumn{5}{|l|}{ [9] Asset value } \\
\hline In highest 25percent & 73 & 2586 & 0.02 & 1.01 \\
\hline In lowest 25 percent & 75 & 861 & & \\
\hline
\end{tabular}

In all other dimensions, the same factors that correlate with drop out also correlate with mental health problems. For example, when we divide the students into different age groups, we find that older aged students are at higher risk of mental health problem than younger students. Students with low math scores (in the bottom 25 percent) are also 5 percentage points more likely to be at risk for mental health problem than students with better scores, which means the poorer achieving students have more anxiety.

Surprisingly, we find that the education levels of fathers but not mothers are significantly correlated with poor student mental health. That is, the students whose fathers did not finish junior high school are 4 percentage points more likely to be at risk for mental health problems. While others in the literature found that mothers are typically more influential for student outcomes (Zhang et al., 2007), one potential reason that fathers matter for mental health outcomes in our study is that fathers with less educational attainment have higher expectations for their children (and thus impose additional mental health costs). By contrast, mothers are traditionally not perceived as the head of the household and may be inflicting fewer mental health costs. Another reason may simply be that paternal education has a higher correlation with increased household income than that of mothers (which then result in better mental health outcomes).

\subsection{Multivariate analysis}

While the cross tabulations in this subsection are interesting, the findings underline the importance of conducting multivariate analysis. Each of the characteristics listed above may predict dropout or risk for mental health problems, but they may not necessarily remain significant if the other variables are controlled for. 
Table 6

Multivariate analysis of determinants of dropout and mental health problems.

\begin{tabular}{lll}
\hline & Dropout & MHT score \\
\hline [1] Female (1=yes) & $-0.02^{* * *}$ & $0.26^{* * *}$ \\
& $(0.01)$ & $(0.04)$ \\
[2] Age (years) & $0.05^{* * *}$ & $0.05^{* * *}$ \\
[3] Boarding (1=yes) & $(0.01)$ & $(0.01)$ \\
& 0.00 & 0.03 \\
[4] Grade 7 (1=yes) & $(0.01)$ & $(0.04)$ \\
& 0.01 & 0.02 \\
[5] Math scores in lowest & $(0.01)$ & $0.04)$ \\
25 percent $(1=y e s)$ & $0.03^{* * *}$ & $0.07^{* * *}$ \\
& & \\
[6] Only child (1=yes) & $(0.01)$ & $(0.03)$ \\
& -0.02 & -0.04 \\
[7] Father completed junior & $(0.01)$ & $(0.05)$ \\
high school $(1=y e s)$ & -0.00 & $-0.09^{* * *}$ \\
& & \\
[8] Mother completed junior & $(0.01)$ & $(0.03)$ \\
high school $(1=y e s)$ & 0.01 & 0.04 \\
[9] Asset in lowest & & \\
25 percent $(1=y e s)$ & $(0.01)$ & $(0.04)$ \\
County dummy & -0.01 & 0.03 \\
Constant & & $(0.04)$ \\
Observations & $(0.01)$ & YES \\
$R$-squared & YES & $-0.85^{* * *}$ \\
\hline
\end{tabular}

Robust standard errors in parentheses ${ }^{* * *} p<0.01$, $^{* *} p<0.05{ }^{*} p<0.1$.

When we run a multivariate regression that includes all the student and family characteristics, we find that boys, older students, and students with lower academic achievement tend to drop out. Boys are 2 percentage points more likely to drop out than the girls (Table 6, column 1, row 1 ). This finding is significant at the $5 \%$ level. As age increases, the dropout rate also increases. Specifically, it increases 5 percentage points per year of age (row 2 ). This finding is significant at the $1 \%$ level. The students whose academic performance is in the bottom 25 percent are shown to have a 3 percentage points higher dropout rate (row 5). This finding is significant at the $1 \%$ level.
Dropout rate and MHT score rank

8.41

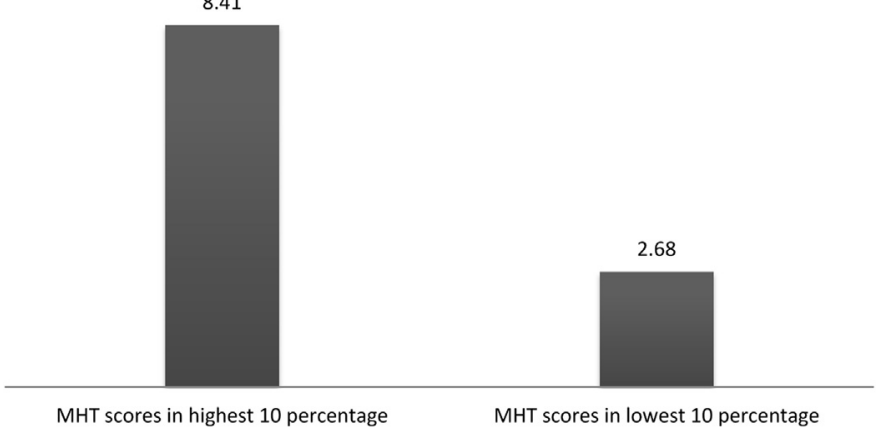

Fig. 4. Dropout rate and MHT score rank.

As with our descriptive results, the same kinds of students who are likely to drop out also are likely to have mental health problems (with exception to girls). Girls, older students, students with lower academic achievement, and students from disadvantaged backgrounds tend to be at risk for mental health problems. Our results show that girls have 0.26 standard deviation higher MHT score than boys, which means they have worse mental health status (Table 6 , column 2, row 1 ). Each year of age predicts a 0.05 standard deviation increase in MHT score, meaning the older students have worse mental health problems (row 2). Students who perform in the bottom 25 percent academically are shown to have a 0.07 standard deviation higher MHT score (row 5). Parents' education level also affects students' mental health: if a student's father completed junior high school or above, the student will have better mental health (a 0.09 standard deviation reduction in MHT score-row 7).

Taken together, then, the same kinds of student and family background characteristics predict both dropout rates and mental health. With only one exception (girls have poorer mental health but drop out less), the coefficients in Table 6 are all in the same direction for dropout or mental health. In sum, our multivariate analysis confirms that findings of the descriptive analysis: dropouts tend to come from disadvantaged families and, in general, students from such families are also at risk for mental health problems.

Table 7

Correlation of student mental health test score to drop out.

\begin{tabular}{llll}
\hline Variables & $(1)$ & $(2)$ & $(3)$ \\
& Drop out & Drop out & $0.010^{* *}$ \\
Drop out
\end{tabular}

Robust standard errors in parentheses ${ }^{* * *} p<0.01,{ }^{* *} p<0.05{ }^{*} p<0.1$.

a Student controls including gender, age, boarding, grade, academic achievement, only child, parent's education status and family economic status.

b Significance tests adjusted for clustering within schools. 


\section{Does mental health correlate with dropout?}

In this section, we examine the correlations between mental health problems and drop out. In Fig. 4, we find that students scoring at the top decile in the MHT (have mental health problems) drop out at a rate of $8.3 \%$, or over three times more than students scoring at the bottom decile of the MHT (no mental health problems). In our unadjusted OLS regression results, we find that mental health is correlated with student drop out. The data show that an increase of one standard deviation on the MHT scores (indicating worse mental health status) is associated with an increase of 1.2 percentage points in dropout (Table 7 , column 1 , row 1$)$.

In our adjusted OLS regression results, we find a similar story: having higher MHT score predicts drop out behavior even after controlling for individual characteristics like age, gender, boarding status, grades, academic performance, number of siblings, parents education status and family economy status. Specifically, an increase of one standard deviation on the MHT scores is correlated with an increase of 1 percentage point in dropout (Table 7, column 2 , row 2). In other words, the magnitude of the association and its statistical significance is similar in both the non-adjusted and adjusted regressions.

The findings continue to hold when we look at associations between dropping out and MHT scores within schools. In our adjusted, school fixed effects regression, we find that mental health problems still correlate with dropout. The results are also statistically significant. Specifically, we find that a student scoring one standard deviation higher on the mental health test (having worse mental health) will also have a 0.9 percentage point higher chance of dropping out.

These results mean that, even when controlling for student, family, and all school characteristics (with fixed effects), mental health problems are still highly correlated with student dropout. So how large is this effect? Is it a meaningful correlation in terms of magnitude? One way to conceptualize a one standard deviation in MHT is to consider that students who at risk and in need of professional counseling score 1.4 standard deviations higher in the MHT than students who are not at risk. This fact strongly suggests that mental health problems contribute to dropout behavior among students.

Of course, it may be the case that these trends differ for certain subgroups of students. As an especially pertinent example, girls are 2 percentage points less likely to drop out than boys and demonstrate 0.26 standard deviations higher mental health (anxiety) scores than boys (Table 6). This trend appears to run counter to the overall idea that dropout and poor mental health are correlated. To better understand these dynamics, we re-run the correlations between dropout and mental health with the inclusion of a gender interaction term. However, even after the gender interaction term is included in our most robust model (the adjusted, school fixed effects regression), we find that the correlation between dropout and mental health scores (anxiety) is still significant. Specifically, we find that a student scoring one standard deviation higher on the mental health test (having worse mental health) will still have a 1 percentage point higher chance of dropping out (the results are significant at 10\% level-Table A2). More importantly, although the fact that the interaction coefficient is negative suggests a potential protective effect of being a girl, the coefficient is not statistically significant. As such, we conclude that the association of mental health scores (anxiety) to dropout appears to hold true among the population at large (both boys and girls).

\section{Conclusions}

In this paper, we found that the average two-year dropout rate in grade 7 and 8 was as high $13 \%$ and ranged from $7.2 \%$ to $27.1 \%$ across different counties. Moreover, we have shown that $74 \%$ of rural students are at risk for mental health problems: for context, this rate is 12 times higher than urban students. Only $5.8 \%$ of urban students taking the MHT test score higher than 7 points (are at risk for mental health problems-Deng et al., 2002). When we decomposed the subcategories of the MHT, we found that most of the risk for mental health problems was driven by learning anxiety.

We further found that, with exception to gender, the same kinds of students (older, lower academic achievement, and disadvantaged family background) were at risk for dropout and mental health problems. Finally, and perhaps most importantly, even after controlling for student and family characteristics, mental health problems are correlated with dropout rates. One standard deviation increase in the MHT (our measure for mental health problems) is correlated with an increase of 0.9 percentage points in dropout. The correlation results were shown to be materially important.

Although these results are focused on the poor rural sample schools, the findings still offer insights into the factors that may contribute to dropout in rural China beyond traditional factors. If mental health in fact drives dropout rates: mental health problems may not only be hurting individual kids, but also hurt China's development in the long run. While we can only guess at the actual reason to explain the connection between mental health and student dropout, one potential reason is that mental health problems (specifically, learning anxiety) disrupt student abilities to learn and thrive in the school context. Students with mental health problems may therefore choose to drop out as a form of escape.

According to China's Ministry of Education statistics, in 2012, there are 33 million junior high students in rural China. If these results hold true across all of rural China, and if $74 \%$ are at risk to have mental health problems, then 25 million junior high students in rural China are at risk for mental health problems. As we found learning anxiety to be the most prevalent mental health problem, it is likely that 22 million children suffer from some form of learning anxiety. Most importantly, 3.7 million students in poor rural areas are dropping out every year before they graduate, and 4.3 million are dropping out between the time they enter grade 7 and before they enter grade 9.

If the association between mental health and dropout rates actually has a causal relationship, mental health problems may be partially contributing to the substantial dropout problem in rural schools every year. In other words, perhaps in part as a result of mental health problems, each year 3.7 million students in rural areas fail to receive the human capital they need to thrive in and drive the future Chinese economy.

Given these findings, we recommend that China's health and education policy makers consider incorporating mental health into their agenda. Mental health programs (such as counselors) are already present in urban schools, but such programs are typically not available in areas of especial need: poor rural schools. From a school perspective, if schools really want to deal with drop out, they might consider focusing on the mental health of their students in addition to their grades. Indeed, an excessive focus on grades in the context of a competitive education system may be driving the high rates of learning anxiety, inadvertently leading to worse mental health problems and drop out. 


\section{Appendix A. Appendix}

Table A1

Breakdown of the mental health test.

\begin{tabular}{|c|c|c|c|}
\hline Mental Health Test-Chinese & Obs & Mean & SD \\
\hline 1.你夜里睡觉时, 是否总想着明天的功课？ & 4665 & 0.54 & 0.50 \\
\hline 2.老师在向全班提问时，你是否会觉得是在提问自己而感到不安？ & 4665 & 0.40 & 0.49 \\
\hline 4.你考试成绩不好时，心理是否感到不快。 & 4665 & 0.79 & 0.40 \\
\hline 5.你学习成绩不好时，是否总是提心吊胆。 & 4665 & 0.66 & 0.47 \\
\hline 7.你考试后，在没有知道成绩之前，是否总是放心不下。 & 4665 & 0.76 & 0.43 \\
\hline 8.你是否一遇到考试，就担心会考坏。 & 4665 & 0.66 & 0.47 \\
\hline 9.你是否希望考试能顺利通过。 & 4665 & 0.93 & 0.26 \\
\hline 10.你在没有完成任务之前，是否总担心完不成任务？ & 4665 & 0.60 & 0.49 \\
\hline 14.你是否做过考试考坏了的梦? & 4665 & 0.42 & 0.49 \\
\hline 15.你是否做过学习成绩不好时, 受到爸爸妈妈或老师训斥的梦? & 4665 & 0.37 & 0.48 \\
\hline 16.你是否常常觉得有同学在背后说你坏话？ & 4665 & 0.46 & 0.50 \\
\hline 17.你受到父母评判后，是否总是想不开，放在心上？ & 4665 & 0.32 & 0.47 \\
\hline 18.你在游戏或与别人的竞争中输给对方，是否就不想再干了？ & 4665 & 0.16 & 0.37 \\
\hline 19.人家在背后议论你，你是否感到讨厌？ & 4665 & 0.63 & 0.48 \\
\hline 20.你在大家面前或被老师提问时，是否会脸红？ & 4665 & 0.44 & 0.50 \\
\hline 21.你是否很担心叫你担任班干部？ & 4665 & 0.29 & 0.45 \\
\hline 28.你和大家在一起时，是否也觉得自己是孤单的一个人？ & 4665 & 0.26 & 0.44 \\
\hline 29.你是否觉得和同学一起玩, 不如自己一个人玩? & 4665 & 0.14 & 0.35 \\
\hline 30.同学们在交谈时, 你是否不想加入? & 4665 & 0.40 & 0.49 \\
\hline 31.你和大家在一起时, 是否觉得自己是多余的人? & 4665 & 0.23 & 0.42 \\
\hline 32. 你是否讨厌参加运动会和文艺演出会 ? & 4665 & 0.22 & 0.42 \\
\hline 33.你的朋友是否很少？ & 4665 & 0.22 & 0.42 \\
\hline 34.你是否不喜欢同别人谈话？ & 4665 & 0.20 & 0.40 \\
\hline 35. 在人多的地方, 你是否觉得很怕? & 4665 & 0.23 & 0.42 \\
\hline 36.你在排球.篮球.足球.拔河.广播操等体育比赛输了时, 是否一直认为自 己不好? & 4665 & 0.34 & 0.47 \\
\hline 37.你受到批评后, 是否总是认为自己不好? & 4665 & 0.50 & 0.50 \\
\hline 38.别人笑你的时候，你是否会认为是自己不用功的缘故? & 4665 & 0.59 & 0.49 \\
\hline 39.你学习成绩不好时, 是否总是认为是自己不用功的缘故？ & 4665 & 0.75 & 0.43 \\
\hline 40.你失败的时候, 是否总是认为是自己的责任? & 4665 & 0.66 & 0.47 \\
\hline 41.大家受到责备时, 你是否认为主要是自己的过错? & 4665 & 0.47 & 0.50 \\
\hline 42.你在乒乓球.羽毛球.篮球.足球.拔河.广播操等体育比赛时, 是否一出错 就特别留神? & 4665 & 0.53 & 0.50 \\
\hline 43. 碰到为难的事情时, 你是否认为自己难以应付? & 4665 & 0.43 & 0.50 \\
\hline
\end{tabular}


Table A1 (Continued)

\begin{tabular}{|c|c|c|c|}
\hline Mental Health Test-Chinese & Obs & Mean & SD \\
\hline 45. 你和同学吵架以后, 是否总是认为是自己的错? & 4665 & 0.46 & 0.50 \\
\hline 46. 你心里是否总想为班级做点好事？ & 4665 & 0.82 & 0.39 \\
\hline 48.你把东西借给别人时, 是否担心别人会把东西弄坏? & 4665 & 0.39 & 0.49 \\
\hline 49.碰到不顺利的事情时，你心里是否很烦躁？ & 4665 & 0.73 & 0.44 \\
\hline 51. 你是否在梦里见过死去的人? & 4665 & 0.40 & 0.49 \\
\hline 52.你对收音机和汽车的声音是否特别敏感? & 4665 & 0.35 & 0.48 \\
\hline 53.你心里是否总觉得好像有什么事没有做好？ & 4665 & 0.57 & 0.50 \\
\hline 54. 你是否担心会发生什么意外的事？ & 4665 & 0.57 & 0.50 \\
\hline 58.你是否经常头痛？ & 4665 & 0.33 & 0.47 \\
\hline 59.你被老师提问时，心里是否总是很紧张? & 4665 & 0.62 & 0.49 \\
\hline 60.你没有参加运动，心脏是否经常噗通噗通地跳？ & 4665 & 0.40 & 0.49 \\
\hline 61.你是否很容易疲劳？ & 4665 & 0.36 & 0.48 \\
\hline 62.你是否很不愿吃药？ & 4665 & 0.54 & 0.50 \\
\hline 63.夜里你是否很难入梦? & 4665 & 0.28 & 0.45 \\
\hline 64. 你是否觉得身体好像有什么毛病？ & 4665 & 0.35 & 0.48 \\
\hline 65.你是否经常认为自己的身型和面孔比别人难看? & 4665 & 0.38 & 0.49 \\
\hline 71.你是否很害怕到高的地方去？ & 4665 & 0.44 & 0.50 \\
\hline 72.你是否害怕很多东西？ & 4665 & 0.37 & 0.48 \\
\hline 73.你是否经常做駩梦？ & 4665 & 0.25 & 0.43 \\
\hline 74.你胆子是否很小？ & 4665 & 0.38 & 0.48 \\
\hline 75. 夜里, 你是否很怕一个人在房间里睡觉？ & 4665 & 0.42 & 0.49 \\
\hline 76.你乘车穿过隧道或高桥时，是否很怕？ & 4665 & 0.30 & 0.46 \\
\hline 77.你是否喜欢夜里开着灯睡觉？ & 4665 & 0.26 & 0.44 \\
\hline 78.你听到打雷声是否非常害怕？ & 4665 & 0.33 & 0.47 \\
\hline 79.你是否非常害怕黑暗？ & 4665 & 0.49 & 0.50 \\
\hline 80.你是否经常感到后面有人跟着你？ & 4665 & 0.54 & 0.50 \\
\hline 81.你是否经常生气? & 4665 & 0.31 & 0.46 \\
\hline 82.你是否不想得到好的成绩 ? & 4665 & 0.15 & 0.36 \\
\hline 83.你是否会突然想哭？ & 4665 & 0.33 & 0.47 \\
\hline 84.你以前是否说过谎话？ & 4665 & 0.71 & 0.46 \\
\hline 85.你有时是否觉得, 还是死了好? & 4665 & 0.28 & 0.45 \\
\hline 86.你是否一次也没有失约过 ? & 4665 & 0.28 & 0.45 \\
\hline 87. 你是否经常想大声喊叫? & 4665 & 0.47 & 0.50 \\
\hline
\end{tabular}


Table A1 (Continued)

\begin{tabular}{|c|c|c|c|}
\hline Mental Health Test-Chinese & Obs & Mean & SD \\
\hline 89.你有时是否想过自己一个人到遥远的地方去? & 4665 & 0.46 & 0.50 \\
\hline 90.你是否总是很有礼貌？ & 4665 & 0.55 & 0.50 \\
\hline 91.你被人说了坏话, 是否想立即采取抱负行动? & 4665 & 0.20 & 0.40 \\
\hline 92.老师或父母说的话, 你是否都照办？ & 4665 & 0.59 & 0.49 \\
\hline 93.你心里不开心，是否会乱丢.乱砸东西？ & 4665 & 0.23 & 0.42 \\
\hline 94.你是否发过怒？ & 4665 & 0.77 & 0.42 \\
\hline 95.你想要的东西, 是否就要一定那到手? & 4665 & 0.17 & 0.38 \\
\hline 96.你不喜欢的课，老师提前下课，你是否感到特别高兴？ & 4665 & 0.47 & 0.50 \\
\hline 97.你是否经常想从高的地方跳下来？ & 4665 & 0.19 & 0.39 \\
\hline 98.你是否无论对谁都很亲？ & 4665 & 0.25 & 0.43 \\
\hline 99.你是否会经常急躁得坐立不安？ & 4665 & 0.33 & 0.47 \\
\hline 100.对不认识的人, 你是否会都喜欢? & 4665 & 0.13 & 0.34 \\
\hline
\end{tabular}

Data source: Authors' survey.

Table A2

Correlations of student mental health test score and rates of drop out.

\begin{tabular}{|c|c|}
\hline Variables & Drop out ${ }^{1,2}$ \\
\hline [1] MHT Score (standardized) & $\begin{array}{l}0.010^{*} \\
(0.005)\end{array}$ \\
\hline [2] MHT Score* Female & $\begin{array}{l}-0.003 \\
(0.006)\end{array}$ \\
\hline [3] Female $(1=y e s)$ & $\begin{array}{l}-0.027^{* * *} \\
(0.008)\end{array}$ \\
\hline [4] Age (years) & $\begin{array}{l}0.044^{* * *} \\
(0.007)\end{array}$ \\
\hline [5] Boarding $(1=y e s)$ & $\begin{array}{l}-0.012 \\
(0.007)\end{array}$ \\
\hline [6] Grade 7 (1=yes) & $\begin{array}{l}0.007 \\
(0.012)\end{array}$ \\
\hline [7] Math scores in lowest 25 percent $(1=y e s)$ & $\begin{array}{l}0.029^{* * * *} \\
(0.009)\end{array}$ \\
\hline [8] Only child $(1=y e s)$ & $\begin{array}{c}-0.014 \\
(0.011)\end{array}$ \\
\hline [9] Father completed junior high school (1=yes) & $\begin{array}{l}-0.002 \\
(0.006)\end{array}$ \\
\hline [10] Mother completed junior high school $(1=y e s)$ & $\begin{array}{l}0.013 \\
(0.008)\end{array}$ \\
\hline [11] Asset in lowest 25 percent $(1=y e s)$ & $\begin{array}{l}-0.017^{* *} \\
(0.008)\end{array}$ \\
\hline County fixed effects & YES \\
\hline Constant & $\begin{array}{l}-0.518^{* * *} \\
(0.092)\end{array}$ \\
\hline Observations & 4615 \\
\hline$R$-squared & 0.121 \\
\hline
\end{tabular}

\section{References}

Angrist, J., Lavy, V., 2009. The effects of high stakes high school achievement awards: evidence from a randomized trial. Am. Econ. Rev. 99, 1384-1414.

Autor, D.H., Levy, F., Murnane, R.J., 2003. The skill content of recent technological change: an empirical exploration. Q. J. Econ. 118, 1279-1333.

Bloom, D.E., Canning, D., 2000. The health and wealth of nations. Science (Washington) 287 (5456) 1207-1209.

Bresnahan, T.F., 1999. Computerisation and wage dispersion: an analytical reinterpretation. Econ. J. 109 (456) 390-415.
Bresnahan, T.F., Brynjolfsson, E., Hitt, L.M., 2002. Information technology, workplace organization, and the demand for skilled labor: firm-level evidence. Q. J. Econ. 117 (1) 339-376.

Brown, P.H., Park, A., 2002. Education and poverty in rural China. Econ. Educ. Rev. 21 (6) 523-541.

Chen, X., Li, B.-S., 2000. Depressed mood in Chinese children: development significance for social and school adjustment. Int. J. Behav. Dev. 24 (4) 472-479.

Clarke, M., Haney, W., Madaus, G., 2000. High Stakes Testing and High School Completion, vol. 1. NBETPP Statements (Number 3).

Connelly, R., Zheng, Z., 2003. Determinants of school enrollment and completion of 10-18 year olds in China. Econ. Educ. Rev. 22 (4) 379-388.

Currie, J., 2009. Healthy, wealthy, and wise: is there a causal relationship between child health and human capital development? J. Econ. Lit. 47 (1) 87-122.

Deng, W., Lei, L., Cao, B., 2002. A survey on mental health of urban middle-school students in Jiangxi Province. Health Psychol. J. 10 (4) (Chinese).

Filmer, D., 1999. The Structure of Social Disparities in Education: Gender and Wealth. World Bank, Development Research Group, Poverty and Human Resources.

Fizbein, A., Shady, N., 2009. Conditional Cash Transfers: Reducing Present and Future Poverty. World Bank, Washington, DC.

Glewwe, P., Kremer, M., 2006. Schools, teachers, and education outcomes in developing countries Handbook of the Economics of Education, vol. 2. , pp. 945-1017.

Hannum, E., Adams, J., 2007. Girls in Gansu, China: expectations and aspirations for secondary schooling. In: Exclusion, Gender and Schooling: Case Studies from the Developing World. Center for Global Development, Washington, DC, pp. 71-98.

Hanushek, E.A., Woessmann, L., 2008. The role of cognitive skills in economic development. J. Econ. Lit. 46, 607-668.

Hanushek, E.A., Woessmann, L., 2012. Schooling, educational achievement, and the Latin American growth puzzle. J. Dev. Econ. 99 (2) 497-512.

Heckman, J.J., Yi, J., 2012. Human Capital, Economic Growth, and Inequality in China, No. w18100 National Bureau of Economic Research.

Kokko, K., Tremblay, R.E., Lacourse, E., Nagin, D.S., Vitaro, F., 2006. Trajectories of prosocial behavior and physical aggression in middle childhood: links to adolescent school dropout and physical violence. J. Res. Adolesc. 16 (3) 403-428.

Luo, R., Shi, Y., Zhang, L., Liu, C., Rozelle, S., Sharbono, B., Yue, A., Zhao, Q., Martorell, R., 2012. Nutrition and educational performance in rural China's elementary schools: results of a randomized control trial in Shaanxi Province. Econ. Dev. Cult. Change 60 (4) 735-772.

Mo, D., Zhang, L., Yi, H., Luo, R., Rozelle, S., Brinton, C., 2011. School dropouts and conditional cash transfers: evidence from a randomized controlled trial in rural China's junior high schools LICOS-Discussion paper series 283/2011, pp. 1-51.

Nolen-Hoeksema, S., Girgus, J.S., Seligman, M.E., 1986. Learned helplessness in children: a longitudinal study of depression, achievement, and explanatory style. J. Personal. Soc. Psychol. 51 (2) 435.

Pintrich, P.R., De Groot, E.V., 1990. Motivational and self-regulated learning components of classroom academic performance. J. Educ. Psychol. 82 (1) 33.

Qiao, L., Chen, X., Yuan, P., Su, W., Zeng, J., 2008. Status of mental health of the left-behind children in certain regions of Sichuan. Mod. Prev. Med. 35 (16) (Chinese). 
Reardon, S.F., Galindo, C., 2002. Do high-stakes tests affect students' decisions to drop out of school? Evidence from NELS. In: Annual Meeting of the American Educational Research Association, New Orleans, LA.

Wang, Yi., 2011. The comparative research on the mental health of rural left-athome children in junior high school. J. UESTC (Social Sciences Edition) 13 (3) (Chinese).

Wang, S., Zeng, J., Shi, Y., Luo, R., Linxiu, Z., 2012. Poor Western regions pupils' differences in gender, health and education. J. Agrotech. Econ. 6, 001 (Chinese).
Yi, H., Zhang, L., Luo, R., Shi, Y., Mo, D., Chen, X., Brinton, C., Rozelle, S., 2012. Dropping out: why are students leaving junior high in China's poor rural areas? Int. J. Educ. Dev. 32 (4) 555-563.

Zhang, G., 2006. A survey on mental health of rural middle-school students. Stud. Psychol. Behav. 4 (3) 180-183 (Chinese).

Zhang, Y., Grace, K., Hannum, E., 2007. Do mothers in rural China practice gender equality in educational aspirations for their children? Comp. Educ. Rev. 51 (2) 131-157. 